Kish, Kathleen V. "Gecser, Ottó, József Laszlovszky, Balázs Nagy, Marcell Sebők, Katalin Szende, eds. 2011. Promoting the Saints - Cults and their Contexts from Late Antiquity until the Early Modern Period - Essays in Honor of Gábor Klaniczay for his $60^{\text {th }}$ Birthday." Hungarian Cultural Studies. e-Journal of the American Hungarian Educators Association, Volume 7 (2014): http://ahea.pitt.edu DOI: 10.5195/ahea.2014.151

\title{
Gecser, Ottó, József Laszlovszky, Balázs Nagy, Marcell Sebők, Katalin Szende, eds. 2011. Promoting the Saints - Cults and their Contexts from Late Antiquity until the Early Modern Period - Essays in Honor of Gábor Klaniczay for his 60th Birthday. Budapest: Central European University Press. 325 pp. Illus.
}

\author{
Reviewed by Kathleen V. Kish, San Diego State University, California
}

This stimulating collection of twenty-two essays draws its inspiration from the rich research record of its dedicatee, Gábor Klaniczay of the Eötvös Loránd University (ELTE) and the Central European University (CEU), both in Budapest, whose eclectic scholarly output in historical and medieval studies is like a beacon, inviting colleagues and students alike to plumb the socio-cultural context of saints. The result is a volume with wide temporal and geographic scope: from the fourth to the eighteenth century and from Egypt to Poland. The types of analyses represented in this volume are likewise diverse, ranging from literary analysis through art history to historical anthropology. Naturally, this choice of subject matter dictates an emphasis on Christian ecclesiastical history, and the favored locus of the material studied is Central Europe, particularly Hungary, although Italy, too, attracts a fair degree of attention. The volume follows an overall chronological scheme, moving from the stories of early Roman martyrs as written on their tombs (Marianne Sághy, "Pope Damasus and the Beginnings of Roman Hagiography," 115) to the use of ritual magic in the popular cult of St. Christopher after 1700 (Benedek Láng, "Saint Christopher: The Patron of Treasure Hunters," 305-10).

This volume's breadth -- of both time and space -- is a tribute to the innovative scholarly oeuvre of Klaniczay, which spans the history of the Long Middle Ages, viewed in the context of cultural history or historical anthropology of societies and civilizations. Klaniczay has become a model for researchers with a wide range of historical interests, as evinced in this collection. An inspiring leader, his connections with other scholars extend outside of Central and Eastern Europe, enriching the international dimensions of Medieval Studies well beyond the academic units that he has founded in Hungarian universities. No wonder, then, that the contributors to his Festschrift are not limited to Hungary, but also include writers in (or with academic associations with) Croatia, Canada, Romania, the United States, Austria, France, and the Czech Republic. The volume as a whole could be thought of as a veritable banquet celebrating sainthood, from the fourth-century appetizer "course" to the eighteenth-century "dessert."

Numerous saints are singled out for special attention: St. Adalbert (Cristian Gașpar, "(Re)claiming Adalbert: Patristic Quotations and their Function in Canaparius' Vita S. Adalberti," 31-39); St. Clement (Patrick Geary, "'Pull you Sons of Whores!': Linguistic Register

$($ (c) $)$ EY

ULIS D-Sente 
Kish, Kathleen V. "Gecser, Ottó, József Laszlovszky, Balázs Nagy, Marcell Sebők, Katalin Szende, eds. 2011. Promoting the Saints - Cults and their Contexts from Late Antiquity until the Early Modern Period - Essays in Honor of Gábor Klaniczay for his $60^{\text {th }}$ Birthday." Hungarian Cultural Studies. e-Journal of the American Hungarian Educators Association, Volume 7 (2014): http://ahea.pitt.edu DOI: 10.5195/ahea.2014.151

and Reform in the Legend of St. Clement," 39-49); St. Francis of Assisi (André Vauchez, "Hagiography and Biography: The Case of St. Francis of Assisi," 59-67; Péter Bokody, "Idolatry or Power: St. Francis in Front of the Sultan,"69-81); St. Margaret (József Laszlovszky, "Fama sanctitatis and the Emergence of St. Margaret's Cult in the Rural Countryside: The Canonization Process and Social Mobility in Thirteenth-Century Hungary," 102-23; and Viktória Hedvig Deák OP, "The Techniques of a Hagiographer: The Two Legendae of Saint Margaret of Hungary, 12536); St. Elizabeth of Hungary (Dávid Falvay, "St. Elizabeth of Hungary in Italian Vernacular Literature: Vitae, Miracles, Revelations, and the Meditations on the Life of Christ," 137-50); St. Stanislaus (Stanislava Kuzmová, "Division and Reintegration of the Body of St. Stanislaus: A Political Analogy in Sermons?," 151-63); St. Sebastian (Ottó Gecser, "Sermons on St. Sebastian after the Black Death (1348-ca. 1500)," 261-72); and St. Anne (Emőke Nagy, "'Had She Born[e] Ten Daughters, She Would Have Named them All Mary because of the Kindness of the First Mary': St. Anne in the Sermons of Two Late Medieval Hungarian Preachers," 273-82).

Several contributors discuss saintly categories or promoters of saints. Ernő Marosi, for example, illumines the Holy Kings of Hungary: Stephen, Ladislaus, and Emeric, in an article adorned with sixteen figures ("Saints at Home and Abroad: Some Observations on the Creation of Iconographic Types in Hungary in the Fourteenth and Fifteenth Centuries," 175-206). Béla Zsolt Szalács profiles István Lackfi, palatine of Hungary, undoubtedly the force behind the construction and decoration of the Franciscan church of Keszthely; this essay concludes with a touching hypothesis about what the murals may tell the viewer about the donor and his family ("Palatine Lackfi and his Saints: Frescos in the Franciscan Church of Keszthely," 207-25, with seven illustrations). Balázs Nagy describes another promoter of saints, Charles IV of Luxemburg ("Saints, Names, and Identities: The Case of Charles IV of Luxemburg," 165-74): born in 1368 and baptized Wenceslas, he would eventually become king of Bohemia and Holy Roman Emperor. Both his autobiography (which reveals his devotion to the Virgin and to St. Catherine of Alexandria) and the Legend of St. Wenceslas, also authored by him, underscore the Luxemburgs' campaign to celebrate their national and dynastic saints, a tendency already noted by Klaniczay in his book Holy Rulers and Blessed Princesses: Dynastic Cults in Medieval Central Europe (Cambridge: Cambridge UP, 2002; see Nagy, 173n35-174n36).

Other themes or tendencies featured in the Festschrift, apart from promoting saints and their cults, concern opposing their veneration for a variety of reasons. György Galamb ("Sainthood in the Propaganda of Mendicant Orders: The Case of the Dialogus contra fraticellos of James of the Marches," 245-59) discusses the attacks on popular piety in the Middle Ages by inquisitors "representing the opinion of the mendicants in addition to the papal policy" (247). Petra Mutlová deals with "The Cult of the Saints in the Bohemian Reformation: The Question of Images" (283-90), pointing out that "[t]he Hussites generally shunned the saints" (283) and arguing convincingly for a more nuanced evaluation of the Hussite iconoclasm than the longstanding one, which has painted all reformers with one brush. The case of the Protestant reformer Peter Paul Vergerius the Younger, as outlined by Marina Miladinov, illustrates the value of a laser-like focus on an individual protest against saints' cults and, especially, of the cult of the Virgin. Miladinov's contribution, "Madonna of Loreto as a Target of Reformation Critique: Peter Paul Vergerius the Younger" (291-303), revolves around a legend concerning the belief that the pilgrimage site in Loreto had been Mary's home in the Holy Land, transported to 
Kish, Kathleen V. "Gecser, Ottó, József Laszlovszky, Balázs Nagy, Marcell Sebők, Katalin Szende, eds. 2011. Promoting the Saints - Cults and their Contexts from Late Antiquity until the Early Modern Period - Essays in Honor of Gábor Klaniczay for his $60^{\text {th }}$ Birthday." Hungarian Cultural Studies. e-Journal of the American Hungarian Educators Association, Volume 7 (2014): http://ahea.pitt.edu DOI: 10.5195/ahea.2014.151

Italy by angels and containing a sacred image painted by none other than the Apostle Luke. Pilgrimage sites such as this one, Miladinov asserts, were roundly condemned by reformers as a "method of snatching money from the credulous and also as an occasion to involve oneself in debauchery" (291).

In the book's Preface (vii-viii) Medievalist and cultural historian Jacques Le Goff (19242014) reviews Klaniczay's outstanding contributions to the profession, emphasizing his recognition of the importance of female holiness, particularly in the thirteenth and fourteenth centuries. Elizabeth of Hungary's claim to fame, Dávid Falvay points out, is secure, given her inclusion in the Legenda Aurea (139). On Hungarian soil, it is St. Margaret's cult that has pride of place in this category, as demonstrated by two of the essayists in the collection. József Laszlovszky traces the marshaling of evidence for her canonization process, drawing attention to "the local cult of saints [in the second half of the thirteenth century]," and showing "how the emerging new cult started to influence the local social milieu" (104). It is worth pausing here to highlight, as Laszlovszky does, the context of his study, namely the revival, led by Klaniczay, of this branch of scholarship in Hungarian Studies after a half-century hiatus (104-05); following Klaniczay's interdisciplinary approach, the author includes a section on "Miracles, Everyday Life, and Archaeology" (108-18). Abounding in pertinent details and illustrated with two line drawings, this essay amply proves its conclusion that "Social mobility in a transforming peasant society and fama sanctitatis were...two interrelated aspects of late thirteenth-century everyday life in the rural countryside" (123). In the companion piece about St. Margaret, Viktória Hedvig Deák OP produces a compelling account of "a hagiographer's 'tricks of the trade" (126); she does this by scrutinizing the two sources in question: the one known as the Legenda Vetus, written shortly after Margaret's death in 1270, and the so-called Legenda Maior (1340). The two sources are so different in structure and content that one might think that they dealt with two different saints. The striking contrasts between the accounts of Margaret's story in these two works, set within the context of her lengthy canonization process, is fascinating, as the author shows how the saint's life story was recast in light of "the then current mystical ideal of holiness, as represented in the lives of the holy women of the Low Countries and in the legends of Dominican penitent women" (128). Furthermore, the author of the more newly created legend sought "to put Margaret's story into the context of salvation history, and make her life resemble the life of Jesus himself" (134). Deák's contribution, thoroughly grounded in the two historical sources, is notable for both the importance of its findings and the liveliness of the account (e.g., it starts with a quotation describing an occurrence of the saint's levitation).

Before concluding, I wish to call attention to the essays that have not already been cited in this review, all of which add to the richness of the volume. Two of these deal with early Christianity. Ildikó Csepregi focuses on "Theological Self-Definition in Byzantine Healing" (1730). Stanko Andrić writes about "Blessed John the French: The First Franciscan Minister Provincial in Hungary, and his Miracles" (83-102) and raises questions about "his troublesome historicity" (102). János M. Bak provides a unique perspective on saints in Central Europe, referring specifically to the Deeds of the Princes of the Poles and the Chronicle of the Czechs ("Hagiography and Chronicles," 51-67), wherein he even finds occasion to refer to Santiago Matamoros in his discussion of "a saint as Schlachtenhelfer" [battle helper] (53). Gerhard Jaritz offers an elegant reflection on the relationship between peasants and the images of saintly 
Kish, Kathleen V. "Gecser, Ottó, József Laszlovszky, Balázs Nagy, Marcell Sebők, Katalin Szende, eds. 2011. Promoting the Saints - Cults and their Contexts from Late Antiquity until the Early Modern Period - Essays in Honor of Gábor Klaniczay for his $60^{\text {th }}$ Birthday." Hungarian Cultural Studies. e-Journal of the American Hungarian Educators Association, Volume 7 (2014): http://ahea.pitt.edu DOI: 10.5195/ahea.2014.151

figures, with sixteen judiciously chosen illustrations ("Late Medieval Saints and the Visual Representation of Rural Space," 227-43).

The impressive array of scholarship presented in this collection will, one hopes, gladden the heart of its worthy honoree. It will also richly reward all those who come to its pages seeking knowledge and inspiration. Finally, the warm reception it is expected to have in various academic circles and interdisciplinary milieus should encourage scholars to follow its pathbreaking studies with still more gems to illuminate the phenomenon of the sacred in its many contexts. 